\title{
Analysis of the impact of tourism sector as a viable response to South Africa's growth and development challenges
}

\author{
Tanya van der Schyff \\ School of Economic Sciences, North-West University \\ South Africa \\ vds.tanya@gmail.com \\ Daniel Meyer \\ School of Economic Sciences, North-West University \\ South Africa \\ daniel.meyer@nwu.ac.za

\section{Lorainne Ferreira} \\ School of Economic Sciences, North-West University \\ South Africa \\ lorainne.ferreira@nwu.ac.za
}

Abstract. Tourism is one of the top-three foreign revenue generating economic sectors globally, representing the total of $7 \%$ in the overal global exports. Overall weak economic and sectoral performance stresses the need for a strong alternative economic sector development so that to support traditional growth sectors which could potentially increase economic growth and development in South Africa. The aim of this study was to analyse the impact of the tourism sector on both economic growth and development in South Africa. There is a gap in literature on the extent and impact of tourism on economic development specifically. This study followes a quantitative research approach by investigating the relationship between tourism and economic growth in the period from 2005 to 2017, as well as tourism and economic development in the period from 1996 to 2016 in South Africa. These relationships were analysed by means of the Johansen cointegration and Vector Error Correction Models. The results indicate there is a long-run relationship between tourism and both economic growth and development. However, no short-run relationship can be validated between tourism and economic growth. A number of policy recommendations that could potentially contribute to the extension of the role of tourism in development include improved stability in the country and relaxation of current visa requirements.

Keywords: economic development, economic growth, South Africa, tourism.

JEL Classification: Z30, Z32 


\section{INTRODUCTION}

Tourism is the $3^{\text {rd }}$ largest foreign revenue generating export sector globally. Back in 2015 it reached the level of USD 1.5 trillion, thus making up seven percent of the total global exports (United Nations World Travel Organization 2016, 5). Although tourism is not considered an official economic sector ${ }^{1}$, it is one of the fastest growing sectors in the world (Akindoabe \& Braimoh 2010,152). Tourism is classified as an elastic sector due to its robustness (World Travel and Tourism Council 2016), meaning that the sector performs well in the face of economic difficulties (Mohr \& Fourie, 2011, p. 162). In addition, De Vita and Kyaw $(2017,423)$ argued that a country's tourism sector can still improve and grow, despite a troubling economic outlook and political uncertainty in it. The global tourism sector achieved 3.9 percent growth in 2016 as compared to the global GDP growth of 2.4 percent (UNWTO, 2017b; World Bank, 2017). In terms of economic growth, tourism contributed 10.2 percent to global GDP growth during 2016 (World Economic Forum, 2017, 3). According to the UNWTO (2015; 2017a) international tourist arrivals, which can be a useful indicator of tourism demand, increased by 4.7 percent during 2014, by 4 percent in 2015 and then by 3.9 percent in 2016.

Nevertheless, South Africa's market share in tourism arrivals declined in 2015 which could be due to significant restrictions in visa regulations, political and social unrest as well as overall weak global economy (Department of Tourism, 2016, 29). This implies the importance of South Africa's tourism through promotion and positive marketing of accommodation, attraction sites and cultures to ensure an increase in international tourism arrivals as well as growth in local tourism (Fourie, 2016). The Travel and Tourism Competitiveness Index by the World Economic Forum ranked South Africa as 53rd out of 141 countries with the competitiveness index value of 4.1, out of 5 in 2017 (World Economic Forum, 2017). The same index also indicated that South Africa's competitiveness has declined and moved 5 places down in the ranking from $48^{\text {th }}$ position back in 2015 .

South African economy has been struggling to achieve high growth rates and has been in a technical recession from the fourth quarter of 2016 to the first quarter of 2017, only escaping it in the second quarter of 2017 (Stats SA, 2017a). This could be the result of various socioeconomic challenges faced by South African citizens, including poverty, unemployment and inequality (Mbele, 2014; Meyer, 2014, 72; Roberts, 2015, 1; Shuaibu \& Oladayo, 2016; Świerczyńska, 2017). According to (Uddin \& Uddin, 2013, 399), various other social and economic problems originate as consequences of unemployment. According to (Stats SA, 2017b), the unemployment rate during the first quarter of 2017 reached 27.7 percent. According to the United Nations World Tourism Organization (2016, 3), 1 out of 11 jobs in 2015 were in the tourism sector. South Africa's tourism sector could therefore potentially contribute to an increase in employment, thus also leading to economic growth and development.

This study analyses the impact of the tourism sector on economic growth and development in South Africa. The initial hypothesis is that development of the tourism sector positively impacts economic growth and development. This research is important since South Africa has been struggling with distribution and utilisation of resources, labour and capital investments especially. Thus, alternative economic sectors need to be highlighted as sufficient contributors to economic growth and development where resources and capacity can be effectively managed with success, and tourism is surely one of such sectors. Most studies have primarily focused on the effect of tourism on economic growth, whereas this article also analyses the

\footnotetext{
${ }^{1}$ Official economic sectors in South Africa include: mining, manufacturing, electricity, construction, trade, transport, and finance categorized in terms of GDP contribution (Stats SA, 2018, 2).
} 
impact of tourism on economic development. This attracts attention to the importance of tourism role in spurring economic recovery in a country like South Africa with so many socioeconomic challenges.

\section{LITERATURE REVIEW}

Tourism is defined as an activity undertaken by individuals who travel to destinations outside their accustomed domain for a period not exceeding one year (OECD 2001). It involves various integrated sectors that includes facilities used for the purpose of both business and leisure. Tourism can further be classified as either inbound or outbound, where inbound tourism refers to the demand by non-residents and outbound tourism the demand by local tourists (Ardahaey 2011, 206 \& OECD 2001, 29; Tóth, 2016; Grobelna \& Dolot, 2018).

Fourie and Burger $(2015,12)$ stated that economic growth, which is the first macro-economic objective of any economy, is an occurrence of the sustained increase of total services and goods from one period to the next defined in terms of GDP (gross domestic product). According to Okun's law, which indicates the relationship between unemployment and economic growth, the decline in the unemployment rate will lead to the elevation of economic growth (Altig, Fitzgerald, Rupert \& Rabin 2012, 135). Furthermore, if population growth exceeds economic growth, the living standards of the individuals within the economy will decrease as employment opportunities are lost (Mohr \& Fourie 2011, 58). However, an increase in employment through tourism could lead to increased economic growth (Gavurova et al. 2018). According to Stats SA (2016) and Smith (2017), South Africa's tourism sector contributed to three percent of overall GDP in 2015 and nine percent in 2016.

According to the Keynes theory, adopted as the general theory in explaining economic growth, total expenditure $(\mathrm{Y})$ consists of consumer spending $(\mathrm{C})$, investments $(\mathrm{I})$, government spending $(\mathrm{G})$, imports $(\mathrm{Z})$ and exports (X) (Fourie \& Burger 2015, 42). Therefore, it is plausible that if individuals, government and firms invest in the tourism sector it should in theory result in economic growth Jahan, Mahumud \& Pageotgiou 2014, 1). The Keynes growth model emphasizes that consumer spending is required to improve economic growth of a country (Mohr \& Fourie 2011, 429). In addition, South Africa has many unskilled labourers that can be employed within the tourism sector as drivers, tour guides, hospitality host, maintenance workers' arts and craftsman as well as salesmen to name only a few (UNWTO 2014, 17). If these individuals receive an adequate income, they will be in an improved financial position to participate in the economy through higher consumption (Dornbusch, Fisher \& Startz 2014, 61).

Bennet $(2000,361)$ states that international arrivals increase when a foreign currency such as the USD appreciates in relation to the ZAR (South African Rand). Since foreign-exchange revenue is accumulated by tourism expenditure, tourist arrivals is therefore also an important determinant of economic growth (Gwenhure \& Odhiambo 2017, 34). According to Solarin $(2014,78)$ international tourism spending increases the foreign exchange reserves of a country that leads to a positive balance of payments. Therefore, tourism is included in the following components; consumer spending, firm investments, government expenditure as well as exports, all contributing to economic growth according to the Keynes theory.

Other theories relating to economic growth are the endogenous growth theory and the neoclassical growth theory (Rivers 2016). According to Dornbusch et al. $(2014,61)$ the neoclassical growth theory states that saving though capital accumulation is crucial to ensure that an economy will grow. Dornbusch et al. $(2014,63)$ further stated that the endogenous models include technology, capital and labour as determining factors. These theories relate to tourism in terms of skill development and technology investment. Investing in technology and skills development in the tourism sector could result in an increase in its contribution to GDP. The relationship between tourism and economic growth is therefore explained by the tourism-led growth hypothesis, which is defined as the presumption that tourism development contributes towards long 
term economic growth (Samimi, Sadeghi \& Sadeghi, 2011, p. 28; Gwenhure \& Odhiambo, 2017, p. 34; Gazda \& Puziak, 2012, p. 112). Since the explanatory power of the available theoretical framework is limited (Błażejowski, Kwiatkowski \& Gazda, 2019), researchers are inclined to adopt a theoretical approach (Błażejowski, Gazda \& Kwiatkowski, 2016).

According to Todaro and Smith $(2011,60)$ and Deaton $(2008,60)$, to ensure an improvement in living standards, an elevation in GNI (gross national income) per capita is required. An increase in GNI could be achieved through job creation or social grants. The latter however is not as sustainable as creating employment opportunities, since it keeps individuals in poverty. According to Amartya Sen (1998), individuals are not only poor when they don't have an income but are also seen as poor if they are not able or capable to function within their communities (Todaro \& Smith 2011, p. 16). If individuals were to have a higher income they could also have a higher self-worth as they will be able to afford better education, better health services that directly leads to higher economic development. Fortunately, there are a diverse range of job opportunities for low- and unskilled, as well as unemployed individuals, especially for the youth in the tourism sector. In theory, it is clear that tourism can supply job opportunities which could lead to an increase in economic growth and economic development (Błażejowski et al. 2016, p. 173).

According to Porter's (1990) competitive advantage theory, if a country, region or firm can provide superior goods or services at a lower cost, they have a competitive advantage. If South Africa can for example offer tourism services exceeding those offered by other countries, more tourist will be visiting South Africa. As such, it is crucial to ensure investment in the tourism sector to increase levels of competitiveness and productivity (Dornbusch et al. 2014, 353). Tourism can therefore be a viable solution to combat various socio-economic challenges faced by the South African economy by expanding the tourism sector in an attempt to gain tourism-related benefits. First, the most valued and significant benefit of tourism is job creation that requires as much technical (such as arts and crafts) as cognitive skills, such as tour guides. Bennet $(2000,358)$ argues that the tourism sector, being labour intensive, is a way for individuals to receive an income. According to the Department of Tourism (2012, p. 1), entrepreneurs can easily enter the tourism sector, as there are limited barriers to entry. Van Aardt, Van Aardt and Bezuidenhout (2000) stated that the tourism sector provides an opportunity for small and medium enterprises to be established in the economy. This gives premise to the benefit of increased employment opportunities. Second, tourism can lead to infrastructure development, for example paved roads and property development (WTTC, 2016, p. 2). This development is crucial for destinations to become and remain competitive. Samini et al. (2011, p. 29) also argues that tourism increases the competitiveness among local companies that could result in improved efficiency of firms (Florek \& Gazda, 2012, p. 37).

There have been numerous studies that analysed tourism-led growth in both developed and developing countries. Kreishan $(2015,6)$ applied an ARDL model to analyse the tourism-led growth hypothesis in Bahrain and found no relationship between tourism and economic growth. In addition, Bento $(2016,169)$ also found the tourism-led hypothesis valid for Portugal. Atan \& Arslanturk $(2012,956)$ investigated the role of tourism in economic growth by means of an input-output method in Turkey, and also found that tourism led to economic growth. Arslanturk, Balcilar and Ozdemir $(2011,668)$ on the other hand, examined the relationship between economic growth and tourist receipts in Turkey, however found no causality between the two variables.

A study conducted by Samimi et al. $(2011,30)$ investigated the long-run relationship as well as the causality between tourism arrivals and economic growth for twenty developing countries by means of a panel vector auto regression (VAR) from 1995 to 2009. The study concluded that a one percent increase in international arrivals causes a 0.68 percent increase in economic growth. Shahzad, Shahbaz, Ferrer and Kunmar (2017, p. 228) studied the impact of tourism-led development on economic growth in Mexico, and found a positive relationship between the development of tourism and economic growth. In addition, Brida, 
Lanzilotta \& Pizzolon (2016) conducted a study on the tourism-led hypothesis study in Brazil and Argentina between 1992 and 2012 and found that the tourism-led growth hypothesis is applicable to Brazil, but not in the case of Argentina. In contrast, Brida et al. (2011) found empirical evidence that no relationship exists between tourism and economic growth for Brazil between 1965 and 2007.

Hye and Khan (2013, p. 310) studied the long-run relationship of economic growth and tourism in Pakistan by means of a Bounds method test between 1971 and 2008. The study concluded that there is a long-run positive relationship and that tourism expenditure leads to economic growth. Tang and Tan (2013, p. 55) also studied the tourism-led hypothesis for Malaysia and also found that the hypothesis to be true. However, Kasimati (2011) found no relationship between tourism and economic growth for Turkey between 1960 and 2006.

Narayan, Narayan, Prasad, \& Prasad $(2011,181)$ investigated the impact of the tourism sector on economic growth for the Pacific Islands which includes the Solomon Islands, Fiji, Tonga and Papua New Guinea Islands by means of a time series analysis from 1988 to 2004. Narayan et al. (2011) found, using a panel Granger Causality test that real GDP leads to tourism growth. Furthermore they noted that in the long-run, tourism growth leads to real GDP growth. A one percent increase in tourism leads to a 0.79 percent increase in real GDP in Fiji, a 0.92 percent increase in real GDP in PNG, a 0.55 percent increase in the Solomon Island and 0.63 percent increase in Tonga in real GDP (Narayan et al., 2011).

Caglayam, Sak and Karymshakov (2012) and Payne and Mervar (2010) made use of a cross sectional or panel method and concluded in a study comprising of 135 countries, between 1995 and 2008, that in Oceania and Eastern and Southern Asia economic growth leads to tourism growth. Payne \& Mervar (2010, p. 1093) examined the tourism-led hypothesis for Croatia from 2000 to 2008 for long-run causality. The economic-led hypothesis was accepted and a uni-directional causality was found where economic growth was moving towards tourism revenues.

According to Webster and Ivanov $(2014,139)$, tourism has a positive and significant contribution to Africa's GDP. They stated that highly competitive countries in tourism, as defined by the Travel and Tourism Competitiveness Index, are more likely to be associated with minor addition in terms of economic growth. Odadiah, Odhaimbo \& Njuguna $(2012,524)$ stated in their study which investigated the tourism and economic growth relationship in Kenya, using time series data and conducting an ARDL test. They concluded that a long- and short-run relationship exists. Odhiambo $(2011,81)$ studied the relationship between economic growth and tourism development for Tanzania by means of a ARDL bounds model. The study found that there exists no direct flow from tourism development to economic growth in the longrun, but rather that economic growth causes tourism development. Akinboade and Braimoh $(2010,149)$ focused on South Africa and conducted a Granger causality study, analysing the causality between tourism earnings from international tourist and economic growth. They found evidence that earnings from international tourists causes economic growth in both the long-and short-run. In this context Jurigová and Lencsésová, (2015) state that contemporary situation of dynamically growing tourism sector urges us to deal with the theme of possible preservation of tourism sources for future generations.

Even though there exists ample research on the impact of tourism on economic growth, very few studies focused on the impact of tourism on economic development. The study by Akinboade and Brainmoh $(2010,155)$ found that there is a relationship between tourism and economic development in South Africa over the period 1980 to 2005. However, their study only focused on international arrivals, using the Johansen Cointegration and VECM methods. This study aims to re-investigate the relationship between tourism and economic development in South Africa for the period 1996 to 2016.

Studies have shown that the development of the tourism sector could lead to an improved economic outlook in terms of economic growth and economic development, especially in the long-run (Tassiopoulos, 2011, p. 6; Gwenhure \& Odhiambo, 2017, p. 34). 


\section{METHODOLOGY}

The study is based on a functionalist theoretical paradigm with a quantitative econometric research design. The study delivers empirical evidence on the relationship between tourism and economic growth and tourism by using quarterly data for the period 2005Q1 to 2017Q1. The period was chosen according to data availability. The study also analyses the relationship between tourism and economic development, using annual data for the period 1996 to 2016, after the 1994 democratic election. Two econometric models are tested with economic growth and economic development as the dependent variables. Log GDP (LGDP) represents the dependent variable in the economic growth model, value at constant prices, expressed in ZAR, Log International arrivals (LIA), Log income of hotels and restaurants (LIHR), represent the tourism sector and the real exchange rate of the ZAR (Zuid-African Rand) against the USD (United States Dollar). Log Exchange rate (LER) are variables used in both the economic growth and economic development models as independent variables. The composite variables for the economic development model variable are the HDI (Human Development Index), employment rate and number of individuals above the poverty line, which measures economic development in a holistic index. The data was obtained from Statistics South Africa (StatsSA), South African Reserve Bank (SARB) and Global Insight.

To test the relationship between tourism and economic growth and between tourism and economic development, the following two models are applied:

$$
\begin{aligned}
\text { Model 1: LGDP } & =\mathrm{f}(\mathrm{LIA}, \text { LIHR, LER }) \\
\text { Model 2: LDEVI } & =\mathrm{f}(\mathrm{LIA}, \text { LIHR, LER })
\end{aligned}
$$

Variables were transformed to their natural logarithm for simplification of the analysis and to reduce the variability of data. Model 1 includes the natural logarithms of the following variables: gross domestic product (LGDP), international arrivals (LIA), income from hotels and restaurants (LIHR) and the real exchange rate between ZAR and USD (LER). Model 2 includes the natural logarithms of the following variables: the Development Index (LDEVI), international arrivals (LIA), income from hotels and restaurants (LIHR) and the real exchange rate between ZAR and USD (LER). Firstly, unit root tests were performed to establish the stationarity of variables. A correlations test, short- run and long-run test were run to indicate the relationship between the economic variables. Lastly, a Granger causality test was done to indicate the causality between variables.

\section{RESULTS AND DISCUSSIONS}

\subsection{Tourism and economic growth (Model 1)}

\subsubsection{Unit root test}

Table 1 presents the results for the Augmented Dickey-Fuller unit root test. The null hypothesis (that the time series variable is non-stationary) is accepted at levels $\mathrm{I}(0)$ for all the variables as these variables are not stationary at a significance level of $5 \%$, indicated by the P-value exceeding 0.05 . After discovering that the variables are non-stationary at levels, the succeeding first difference stationarity test is executed. The null hypothesis is rejected at first difference I(1) as all the variables are stationary at a significance level of $1 \%$ as indicated by the P-value of below 0.01 . Thus, the variables are all stationary at first difference or $\mathrm{I}(1)$. 
Augmented Dickey-Fuller Unity Root Test

\begin{tabular}{|c|c|c|c|c|c|}
\hline \multirow{2}{*}{ Variables } & \multicolumn{2}{|c|}{ Level I(0) } & \multicolumn{2}{c|}{ First Difference I(1) } & Result \\
\cline { 2 - 6 } & t-stat & P-value & t-stat & P-value & \\
\hline LGDP & -3.7685 & 0.0660 & -7.0433 & $0.0002^{*}$ & $\mathrm{I}(1)$ \\
LIA & -1.9716 & 0.2979 & -12.187 & $0.0006^{*}$ & $\mathrm{I}(1)$ \\
LIHR & -2.5990 & 0.1002 & -5.5977 & $0.0007^{*}$ & $\mathrm{I}(1)$ \\
LER & -1.9896 & 0.2903 & -8.9765 & $0.0005^{*}$ & $\mathrm{I}(1)$ \\
\hline
\end{tabular}

Note: * signifies stationary variable below a significance level of $1 \%$.

\subsubsection{Correlation analysis}

Table 2 presents the result from the correlation analysis which indicates the relationship between the variables. The correlation analysis points out that strong positive relationships exist between the dependent variable LGDP, and each of the independent variables LIA, LIHR and LER respectively at a significance level of $1 \%$.

Table 2

Correlation Analysis

\begin{tabular}{|c|c|c|c|c|}
\hline & LGDP & LIA & LIHR & LER \\
\hline LGDP & 1.0000 & 0.9658 & 0.9195 & 0.8094 \\
& ---- & {$[0.0005]^{*}$} & {$[0.0002]^{*}$} & {$[0.0008]^{*}$} \\
\hline
\end{tabular}

Note: P-values in []. * signifies stationary variable below a significance level of $1 \%$.

\subsubsection{Co-integration test results}

Due to the fact that the unit root test results is $\mathrm{I}(1)$, the Johansen co-integration test was performed. Before the Johansen co-integration test is conducted, a lag length selection criteria was used to establish the number of lags to be used. The selection criteria concluded that 2 lags are to be used. Table 3 presents the results for the Max-Eigenvalue and Trace test within the Johansen co-integration test. The Johansen cointegration test indicate the presence of co-integration. The Trace test is supported by the Maximum Eigenvalue as the $\mathrm{H}_{0}$ is rejected for both at a significance level of $1 \%$. The rejection of the $\mathrm{H}_{0}$ indicates that the series have a long-run relationship.

Table 3

Johansen co-integration

\begin{tabular}{|c|c|c|c|c|c|c|}
\hline \multirow{2}{*}{$\begin{array}{c}\mathbf{H}_{\mathbf{0}} \text { : No. of } \\
\text { CE(s) }\end{array}$} & \multicolumn{3}{|c|}{ Trace test } & \multicolumn{3}{c|}{ Maximum Eigenvalue } \\
\cline { 2 - 7 } & Trace & T-critical & P-values & Max-Eigen & T-critical & P-values \\
& statistic & Value & & Statistic & values & \\
None & 81.52318 & 47.85613 & $0.0000^{*}$ & 45.41419 & 27.58434 & $0.0001^{*}$ \\
At most 1 & 36.10899 & 29.79707 & $0.0082^{*}$ & 19.11594 & 21.13162 & 0.0935 \\
At most 2 & 16.99306 & 15.49471 & $0.0295^{* *}$ & 12.16506 & 14.26460 & 0.1046 \\
\hline
\end{tabular}

Note: * signifies rejection of $\mathrm{H}_{0}$ at the significance level of $1 \%$, ** signifies rejection of $\mathrm{H}_{0}$ at the significance levels of $5 \%$. 
The long-run equation is indicated in Equation (3):

$$
\mathrm{Eq}(1): \mathrm{LGDP}=6.580825+0.85443(\mathrm{LIA})+0.151449(\mathrm{LIHR})+0.85403(\mathrm{LER})
$$

In the long-run, there is a positive relationship between the dependent and independent variables. Meaning that an increase in the independent variables, LIA, LIHR and LER causes an increase in LGDP. Therefore, a one percent increase in the number of international arrivals (LIA) cause a 0.85 percent increase in GDP. Furthermore, a one percent increase in the income generated from hotels and restaurants (LIHR) causes a 0.15 percent increase in GDP. Lastly, a one percent increase (depreciation) of the ZAR causes a 0.85 percent increase in GDP. These findings are in line with those of Narayan et al., (2011) who found that in the long-run in the Pacific Islands, tourism growth led to real GDP growth with coefficients 0.79 in Fiji, a 0.92 coefficient in Papua New Guinea islands, a 0.55 coefficient in the Solomon Islands and 0.63 coefficient in Tonga in real GDP.

The Vector Error Correction Model indicates that there exists no short-run relationship between economic growth and tourism development. A study by Odadiah, Odhaimbo \& Njuguna (2012) agrees with this result, as a positive long-run relationship was found in Kenya. The results of Akinboade and Braimoh's (2010) study agrees with Odadiah et al. (2012) as they found that in the case of South Africa, earnings from international tourist causes economic growth in the long-run. Table 5 presents the Vector Error Correction Model. Equation 1 describes the short-run change in the long-run equilibrium. Table 5 indicates that there exists no short-run relationship between economic growth and tourism as none of the variables are negative or significant at the 5 percent significance level.

Table 4

Vector Error Correction Model

\begin{tabular}{|c|c|c|c|c|}
\hline Error Correction: & D(LGDP) & D(LIA) & D(LIRH) & D(LER) \\
\hline CointEq1 & $-0.028966^{* *}$ & 1.344132 & 0.098651 & -0.219065 \\
& {$[-0.64941]$} & {$[6.68392]$} & {$[0.30620]$} & {$[-0.33378]$} \\
D(LGDP(-1)) & -0.004554 & 0.699371 & 1.288618 & 2.508704 \\
& -0.02662 & {$[0.90679]$} & {$[1.04290]$} & {$[0.996655]$} \\
D(LIA $(-1))$ & 0.019426 & 0.401179 & 0.104872 & 0.078410 \\
& {$[-0.65387]$} & {$[2.99505]$} & {$[0.48870]$} & {$[0.17936$} \\
D(LIRH(-1)) & -0.017761 & 0.136987 & 0.126065 & -0.254158 \\
& {$[-0.77122]$} & {$[1.31928]$} & {$[0.75783]$} & {$[-0.74999]$} \\
D(ER(-1)) & -0.000941 & 0.054722 & -0.036155 & -0.280767 \\
& {$[-0.08887]$} & {$[1.14676]$} & {$[0.47293]$} & {$[-1.80281]$} \\
\hline
\end{tabular}

Note: $*$ denotes significant at $1 \%$. $* *$ denotes significant at $5 \%$.

\subsubsection{Pairwise Granger Causality}

The results of the Granger causality test (Table 4) shows a uni-directional relationship between GDP to international arrivals and exchange rate. A uni-directional relationship is also found from the exchange rate to income from restaurants and households as the changes in exchange rates influences the changes in income generated from restaurants and hotels. Granger causality was also found from international arrivals to the exchange rate as changes in international arrival Granger causes change in the exchange rate. It is interesting to note international arrivals and income generated from restaurants and hotels does not cause changes in GDP in the short-run. 
In summary, the results show a one-way relationship between GDP and the exchange rate, the exchange rate and income from hotels and restaurants, international arrivals and the exchange rate. The Granger test shows that tourism does not cause economic growth. This result is similar to studies by Arslanturk (2011) who examined the relationship between economic growth and tourist receipts and found no causality for Turkey. In addition, Arslanturk (2011) agrees with Kasimati (2011) who also found no relationship between tourism and economic growth for Turkey between 1960 and 2006, including GDP, exchange rate and international arrivals into a country as variables. However, the test results are contrary to Kreishan (2015) whose findings concluded that the tourism-led growth hypothesis of Bahrain, and found the hypothesis of Bahrain to be true. Thus, tourism growth led to economic growth.

Table 5

Granger Causality

\begin{tabular}{|l|c|c|}
\hline & F-statistic & P-value \\
\hline LIA does not Granger cause LGDP & 0.13329 & 0.8756 \\
LGDP does not Granger cause LIA & 12.4792 & $0.0051^{*}$ \\
LIRH does not Granger cause LGDP & 0.98669 & 0.3813 \\
LGDP does not Granger cause LIRH & 1.84329 & 0.1709 \\
LER does not Granger cause LGDP & 0.04045 & 0.9604 \\
LGDP does not Granger cause LER & 5.3532 & $0.0085^{*}$ \\
LIRH does not Granger cause LIA & 0.44297 & 0.6451 \\
LIA does not Granger cause LIRH & 1.03499 & 0.3641 \\
LER does not Granger cause LIA & 0.96535 & 0.3891 \\
LIA does not Granger cause LER & 4.35689 & $0.0191^{* *}$ \\
LER does not Granger cause LIRH & 4.15038 & $0.0227^{* *}$ \\
LIRH does not Granger cause LER & 2.25223 & 0.1177 \\
\hline
\end{tabular}

Note: * signifies rejection of Granger causality null hypothesis at the significance level of 1\%, ** signifies rejection of Granger causality null hypothesis at the significance levels of $5 \%$.

\subsection{Tourism and Economic development (Model 2)}

\subsubsection{Descriptive statistics}

Figure 1 shows the descriptive graphs of the following variables; the Development Index, international arrivals, income from restaurants and hotels and the exchange rate. The graph portraying the Development Index shows a significant decline between 1996 and 2003 in the standards of living of South Africans. Since 2003 the Development Index increased substantially as the graph indicates a positive trend showing an overall improvement in living standards. A study done by Alm and Embaye (2011,2) found that South Africa's government spending increased significantly between 1994 and 2007. This shows an attempt by the government to increase the overall living standards and could possibly result in an increase in the HDI, employment rate and number of people above the poverty line. However, since 2015 South Africa experienced a slight decrease in overall economic development. Elevated unemployment rates, poor health services and decreased government spending could be a possible causes for this declining phenomena. South Africa experienced a high unemployment rate of 26.7 percent in 2016 due to restricted labour regulations and poor economic performance which also contributed to this decline in the Development Index (Stats SA 2016). The United Nations Development Programme (2016) indicated that between 2005 and 2015 South Africa's HDI ranking increased from 0.609 to 0.666 , life expectancy increased from 51.6 to 57.7 and averaged years of schooling from 8.9 to 10.3 and income per capita increased from $\$ 10953$ to $\$ 12$ 087. It 
is plausible that if the number of years of schooling, the life expectancy and the income per capita increased, nationals could have increased living standards, resulting in higher economic development.

As one of the key indicator of tourism development, the changes in international tourist arrivals is crucial to be analysed. The number of international tourist arrivals increased at a consistent rate between 1996 and 2004. During the 2010 Soccer World Cup, the number of international arrivals increased above the 1000000 mark. The Soccer World Cup brought about an increase in the number of tourist arrivals in 2010. A positive upward trend in income from hotels and restaurants as these facilities increased investment into companies to remain competitive in the market. Between 2013 and 2015 there was minimal growth in terms of tourist arrivals. A Possible reason for this could be the strict visa regulation implemented during this period to protect children against trafficking. This worsened the workload of the Department of Immigration, causing delays in processing of applications.

In the case of income generated from restaurants and hotels, a positive upward trend is noticed from 2002 to 2007. From mid-2008 until mid-2009 income generate from restaurants and hotels declined. This could be due to the adverse consequences of the global financial crisis of 2007/9 having troubling impacts on all markets. Up until mid-2010 there was a sharp increase in the income of restaurants and hotels, with the 2010 Soccer World Cup contributing greatly towards this sector, Stabilisation occurred between 2011 and 2016 with limited growth recorded.

The exchange rate shows much more volatility than any of the other variables. South Africa's exchange rate is influenced by both internal and external factors such as political instability and the safety in both national and international countries. A significant increase in the exchange rate is noted between 1996 and 2002, which indicates the depreciation of the Rand against the USD. Since then, a sharp decline continued for the next year. Between 2003 and 2009 a relatively consistent trend in the exchange rate can be seen. The exchange rate high from 2007 to 2008, as this time-period was characterised by an international crisis, a national electricity crisis which cause production output cuts and in severe case closures of mines. In 2010 the exchange rate appreciated. It is possible that the 2010 Soccer World Cup lead to an increased demand for South African Rand, which increased its value. However, after the 2010 Soccer World Cup there has been a sharp depreciation of the Rand against the USD from 2011 until 2016, and it is possible that political instability contributed greatly to this.
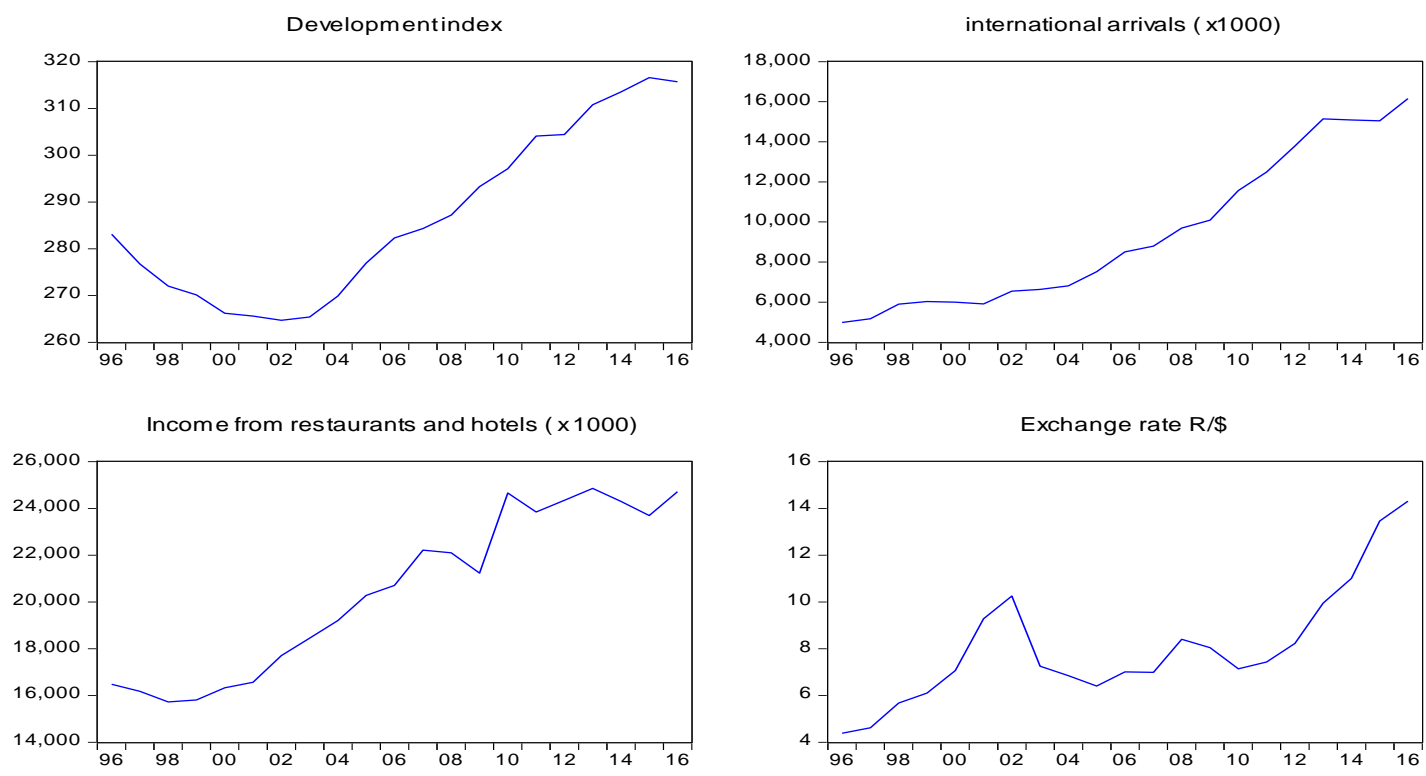

Figure 1. Descriptive graphs 
Due to the fact that there are only 20 annual observations for the long-run relationship, a test between tourism and economic development could not be performed. Only the short-run analysis was performed.

\subsubsection{Unit Root test}

Table 6 shows the results for the Augmented Dicky-Fuller unit root test. The null hypothesis is accepted at levels $I(0)$ as all the variables are non-stationary at a significance of $5 \%$. However, the null hypothesis is rejected at first difference $\mathrm{I}(1)$ as all variables are stationary at a significance level of 5 . Thus, variables have no unit root.

Table 6

Augmented Dickey-Fuller Unit Root Test

\begin{tabular}{|c|c|c|c|c|c|}
\hline Variables & \multicolumn{2}{c}{ Level I(0) } & \multicolumn{1}{c|}{ First Difference I(1) } & Result \\
\hline & t-stat & P-value & t-stat & P-value & \\
\hline LDEVI & 1.748652 & 0.9762 & -2.942711 & $0.0056^{*}$ & $\mathrm{I}(1)$ \\
LIA & 0.110824 & 0.9583 & -4.156720 & $0.0051^{*}$ & $\mathrm{I}(1)$ \\
LIHR & -0.712783 & 0.8204 & -5.353869 & $0.0004^{*}$ & $\mathrm{I}(1)$ \\
LER & 0.935139 & 0.7550 & -3.253571 & $0.0324^{* *}$ & $\mathrm{I}(1)$ \\
\hline
\end{tabular}

Note: * signifies stationary variable below a significance level of 1\%, ** signifies stationary variables below a significance levels of $5 \%$.

\subsubsection{Correlation Analysis}

The results from the correlation analysis is presented in Table 7 below. It was found that positive and significant relationships exist between the dependent variable (LDEVI) and all the independent variables.

Correlation Analysis

\begin{tabular}{|l|l|l|l|l|}
\hline & LDEVI & LIA & LIHR & LER \\
\hline LDEVI & 1.0000 & 0.9222 & 0.8613 & 0.5608 \\
& ----- & {$[0.0000]^{*}$} & {$[0.0000]^{*}$} & {$[0.0082]^{*}$} \\
\hline
\end{tabular}

Note: P-values in []. * signifies stationary variable below a significance level of $1 \%$.

\subsubsection{Pairwise Granger Causality test}

Table 8 below presents the result from the Granger causality test. The null hypothesis is rejected if the variable is significant in causing a change in other variables. Therefore, in the short-run; there exists a bidirectional relationship between international arrivals and the development index, as well as between income from hotels and restaurants and the development index.

However, a uni-directional short-run relationship is noted between income from hotels and restaurants and international arrivals. A plausible reason for this can be that international tourist are more likely to visit a destination with new and improved accommodation and food facilities. In addition, LIA causes LER in the short-run, the changes in the number of international arrivals will influence the change in the exchange rate. When the number of individuals visiting a destination from abroad increase, the exchange rate will also increase as there are changes in the demand for currency. However, a uni-directional relationship is noted between income from hotels and restaurants, even though international arrivals causes exchange rate 
fluctuations. This means that the development in tourism could contribute to the growth in income generated by hotels and restaurants and that progress in the hotel and restaurant sector could lead to the development in the tourism sector.

Table 8

Granger Causality Test

\begin{tabular}{|l|c|c|}
\hline \multicolumn{1}{|c|}{ Null Hypothesis } & F-statistic & P-value \\
\hline LIA does not Granger cause LDEVI & 3.51297 & $0.0580^{* * *}$ \\
LDEVI does not Granger cause LIA & 3.67760 & $0.0520^{* * *}$ \\
LIHR does not Granger cause LDEVI & 11.1351 & $0.0013^{*}$ \\
LDEVI does not Granger cause LIHR & 3.73948 & $0.0500^{* *}$ \\
LER does not Granger cause LDEVI & 1.50779 & 0.2553 \\
LDEVI does not Granger cause LER & 3.24138 & $0.0697^{* * *}$ \\
LIHR does not Granger cause LIA & 4.57603 & $0.0296^{* *}$ \\
LIA does not Granger cause LIHR & 0.20873 & 0.8141 \\
LER does not Granger cause LIA & 1.04473 & 0.3777 \\
LIA does not Granger cause LER & 13.0534 & $0.0006^{*}$ \\
LER does not Granger cause LIHR & 2.00595 & 0.1714 \\
LIH does not Granger cause LER & 1.01763 & 0.3867 \\
\hline
\end{tabular}

Note: * signifies rejection of Granger causality null hypothesis at the significance level of $1 \%$, ${ }^{* *}$ signifies rejection of Granger causality null hypothesis at the significance levels of $5 \%$ and $* * *$ signifies rejection of Granger causality null hypothesis at the significance levels of $10 \%$.

\section{RECOMMENDATIONS AND CONCLUSIONS}

South Africa is faced with various socio-economic challenges such as unemployment, low growth, poverty and inequality as well as underperforming main economic sectors. Socio-economic challenges have contributed to South Africa's overall weak economic performance since 1994. In order to reduce some of these socio-economic challenges and spur economic recovery, it is important to recognise the importance of a sector such as tourism and the contributions this sector can make to growth and development in the country.

Tourism is one of the leading economic sectors globally, and South Africa is no exception. South Africa's tourism sector has been a vital part of the country's growth and development in recent years. Therefore, this study quantified the impact of tourism on economic growth as well as economic development in South Africa to illustrate the importance and contribution of this sector and show why it is important to invest in and develop this sector. The results from the Johansen co-integration estimation showed that there is a long-run relationship between tourism and economic growth, between the period 2005 to 2017, as well as tourism and economic development, between the period 1996 to 2016. Interestingly however, the result showed no short-run relationship between economic growth and tourism. This study contributed to existing literature by also indicating the effect of tourism on economic development. One of the limitations of this study is that the short-run relationship between tourism and economic development could not be validated as all the variables were not stationary $i(0)$. Future research can investigate which of the sub-sectors (transport, accommodation, entertainment and food) contributes the most to the development of the tourism sector. 
The following recommendations can be made based on the findings; (i) increase efficiency within the Department of Home Affairs in order to decrease the processing time of visa applications. (ii) Temporary visas should also be provided as a means of decreasing the difficulty and time of application approval. Thus, an amendment of visa regulations is needed to ensure an easier application process that will encourage international arrivals. (iii) Financial aid and management advice should be made available to new entrepreneurs entering the tourism sector. Even though entry to the tourism sector is relatively open, financial and management issues limit the abilities of an entrepreneur to be successful.

In conclusion, South Africa is in need of a sector to drive higher economic growth and development. The tourism development is a contributor to economic growth in the long-run and could possibly lead to an increase in economic development. Even though tourism is regarded as an unofficial economic sector, this research highlights this sector as one which the private and public sector should invest in as a means of reducing the various socio-economic challenges and spur economic recovery in South Africa.

\section{REFERENCES}

Akinboade, O. A. \& Braimoh, L. A. (2010). International tourism and economic development in South Africa: A granger causality test. International Journal of Tourism Research, 12(2), 149-163.

Altig, D., Fitzgerald, T., Rupert, P. \& Rabin, J. (2012). Handbook of monetary policy. NY: Marcel Dekker, Inc.

Alm, J \& Embaye, A. (2011). Explaining the growth of government spending in South Africa. South African Journal of Economics, 78(2), 152-169.

Ardahaey, F.T. 2011. Economic impacts of tourism industry. International Journal of Business and Management, 6(8), 206215.

Arslanturk, Y., Balcilar, M. \& Ozdemir, Z.A. (2011). Time-varying linkages between Tourism Receipts and Economic Growth in a small open economy. Economic Modelling, 28, 664-671.

Atan, S. \& Arslanturk, Y. (2012). Tourism and economic growth nexus: An input-output analysis in Turkey. Social and Behavioral Sciences, 62, 952-956.

Bennett, J.A. (2000). Managing tourism services: A Southern African perspective. $2^{\text {nd }}$ ed. Hatfield, Pretoria: Van Schaik Publishers.

Bento, J.P.C. (2016). Tourism and economic growth in Portugal: An empirical investigation of causal links. Tourism \& Management Studies, 12(1), 164-171.

Błażejowski, M.; Kwiatkowski, J.; Gazda, J. (2019), Sources of Economic Growth: A Global Perspective. Sustainability, 11, 275.

Błazejowski, M.; Gazda, J.; Kwiatkowski, J., (2016), Bayesian Model Averaging in the Studies on Economic Growth in the EU Regions - Application of the gretl BMA Package. Econonomics \& Sociology, 9, 168-175.

Brida, J., Lanzilotta, B. \& Pizzolon, F. (2016). Dynamic relationship between tourism and economic growth in MERCOSUR countries: A nonlinear approach based on asymmetric time series models. Economics Bulletin, 36(2), 879-894.

Brida, J.G., Monterubbianesi, P.D. \& Zapata-Aguirre, S. (2011). Impacts of tourism on economic growth and development. The case of the main tourist destinations in Colombia. Journal of Tourism and Cultural Heritage, 9(2), 291-303.

Caglayan, E., Sak, N. \& Karymshakov, K. (2012). Relationship between tourism and economic growth: A panel Granger causality approach. Asian Economic and Financial Review, 2(5), 591-602.

Deaton, A. (2008). Income, health and well-being around the world: Evidence from the Gallup World Poll. Journal of Economic Perspectives, 22(2), 53-72.

Department of Tourism. (2012). National tourism sectoral strategy. Pretoria: Government Printer.

Department of Tourism. (2016). Annual report. 2015/2016. Pretoria: Government Printer.

De Vita, G.D. \& Kyaw, K.S. (2017). Tourism specialization, absorptive capacity and economic growth. Journal of Travel Research, 56(4), 423-435.

Dornbusch, R., Fisher, S. \& Startz, R. (2014). Macroeconomics. 12 ${ }^{\text {th }}$ ed. Singapore: McGraw Hill Education. 
Florek, M., Gazda, J., (2012), Economic and non-economic effects of hosting mega sport events. Poland and the UEFA EURO 2012 case study, Actual Problems of Economics, 2(7).

Fourie, F.C.V.N, \& Burger, P. (2015). How to think and reason in macroeconomics. $4^{\text {th }}$ ed. Cape Town: Juta and Company.

Fourie, J. (2016). How to boost tourism in SA. Retrieved April 9, 2017 from http://m.fin24.com/fin24/Finweek/Opinion/how-to-boost-tourism-in-sa-20160620..

Gavurova, B., Kocisova, K., Behun, M., \& Tarhanicova, M. (2018). Environmental performance in OECD countries: A non-radial DEA approach. Acta Montanistica Slovaca, 23(2), 206-215.

Gazda, J., \& Puziak, M., (2012). The Sources of Economic Growth in the Regions. In Stages of the Convergence in the Developed European Economies; Kokocinska, M., Ed.; Poznan University of Economics Press: Poznan, Poland, 107-125.

Grobelna, A., \& Dolot, A. (2018). The Role of Work Experience in Studying and Career Development in Tourism: A Case Study of Tourism and Hospitality Students from Northern Poland. Entrepreneurial Business and Economics Review, 6(4), 217-229.

Gwenhure, Y. \& Odhiambo, N.M. (2017). Tourism and economic growth: A review of international literature. Tourism (Zagbreb), 65(1), 33-44.

Hendriks, J.F. (2016). Critical evaluation of possible policy options to reduce unemployment in South Africa. (Masters thesis University of the Western Cape.

Hye, Q.M.A. \& Khan, R.E.A. (2013). Tourism-led growth hypothesis: A case study of Pakistan. Asia Pacific Journal of Tourism Research, 18(4), 303-313.

Jahan, S., Mahumud, S. \& Pagageotgiou, C. (2014). What is Keynesian economics. Back to Basics, 51(1), 1-2.

Jurigová, Z., \& Lencsésová, Z. (2015). Monitoring System of Sustainable Development in Cultural and Mountain Tourism Destinations. Journal of Competitiveness, 7(1), 35-52.

Kasimati, E. (2011). Economic impact of tourism on Greece's economy: Cointegration and causality analysis. International Research Journal of Finance and Economics, 79, 79-85.

Kreishan, F.M. (2015). Empirical study on tourism and economic growth of Bahrain: An ARDL bounds testing approach. International Journal of Economics and Finance, 7(7), 1-9.

Maloney, W.F. \& Montes Rojas, G.V. (2011). Demand for tourism. The World Bank, Washington, DC.

Mbele, L. (2014). South Africa's economic challenges. http://www.bbc.com/news/Business-27291240. Retrieved April 20, 2017.

Meyer, D. F. (2014). Job creation, a mission impossible? The South African case. Mediterranean Journal of Social Science, 5(6), 65-77.

Mohr, P. \& Fourie, L. (2011). Ekonomie vir Suid Afrikaanse studente. 4de ed. Hatfield, PTA: Van Schaik Publishers.

Narayan, P.K., Narayan, S., Prasad, A. \& Prasad, B.C. (2010). Tourism and economic growth: A panel data analysis for Pacific Island countries. Tourism Economic, 16(1), 169-183.

National Treasury. (2017). Budget Speech 2017. Pravin Gordhan. http://www.treasury.gov.za /document/national\%20budget/2017/speech.pdf. Retrieved March 8, 2017).

Obadiah, N.K., Odhiambo, N.M. \& Njuguna, J.M. (2012). Tourism and economic growth in Kenya: An empirical investigation. International Business \& Economics Research Journal, 11(5), 517-528.

Odhiambo, N.M. (2011). Tourism development and economic growth in Tanzania: Empirical evidence from the ARDL-bounds testing approach. Economic Computation \& Economic Cybernetics Studies and Research, 45(3), 71-83.

OECD (Organization of Economic Co-operation Development). (2001). Tourism satellite account: Recommended methodological framework. Eurostat, OECD, WTO, UNSD.

Payne, J.E. \& Mervar, A. (2010). The tourism growth nexus in Croatia. Tourism Economics, 16(4), 1089-1094.

Porter, M.E. (1990). The competitive advantage of nations. Harvard Business Review, 68(2), 73-93.

Rivers, M.A. (2016). The synergies between human development, economic growth and tourism within a developing country: An empirical model of Ecuador.. PhD Thesis. University of Central Florida. Orlando, Florida.

Roberts, G.A. (2015). The dimensions of youth unemployment in South Africa. PhD - Thesis. Uiversity of the Witwatersrand. 
Samimi, A.J., Sadeghi, S. \& Sadeghi, S. (2011). Tourism and economic growth in developing countries: P-VAR approach. Middle-East Journal of Scientific Research, 10(1), 28-32.

Shahzad, S.J.H., Shahbaz, M., Ferrer, R. \& Kunmar, R.R. (2017). Tourism-led growth hypostasis' in the top ten tourist destinations: New evidence using quantile-on-quantile approach. Tourism Management, 60(2), 223-232.

Shuaibu, M. \& Oladayo, P. (2016). Determinants of human capital development in Africa: a panel data analysis. Oeconomia Copernicana, 7(4), 523-549. https://doi.org/10.12775/OeC.2016.03.

Smit, A.J. (2010). The competitive advantage of nations: Is Porter's diamond framework a new theory that explains the international competitiveness of countries? Southern African Business Review, 14(1), 105-130.

Smith, C. (2017). Travel and tourism to contribute R412.2bn to SA's GDP in 2017. http://www.fin24.com/economy/trave-and-tourism-to-contribute-r412.2bm to SA's GDP in 2017. Retrieved 25 Oct. 2017.

Solarin, S.A. (2014). Revisiting the convergence hypothesis of tourism markets: Evidence from South Africa. The Journal of Applied Economic Research, 8(1), 77-92.

Stats SA (Statistics South Africa). (2016). Tourism: jobs, the economy and spending. http://www.statssa.gov.za/?p=9264. Retrieved March 8, 2017.

Stats SA (Statistics South Africa). (2017a). Agriculture and finance help lift SA out of recession. http://www.statssa.gov.za/?p=10426. Retrieved September 26, 2017.

Stats SA (Statistics South Africa). (2017b). Work \& labour force: Key statistics. http:/ /www.statssa.gov.za/?page id=737\&id=1. Retrieved April 20, 2017.

Stats SA (Statistics South Africa). (2018). Gross domestic product: Fourth quarter 2017. http://www.statssa.gov.za/?page_id=1854\&PPN=PO441\&SCH=6985. Retrieved April 27, 2018.

Szivas, E. \& Riley, M. (1999). Tourism employment during economic transition. Annuals of Tourism Research, 26(4), 747771.

Świerczyńska, K. (2017). Structural transformation and economic development in the best performing sub-Saharan African states. Equilibrium. Quarterly Journal of Economics and Economic Policy, 12(4), 547-571. https://doi.org/10.24136/eq.v12i4.29.

Tang, C. \& Tan, E.C. (2013). How stable is the tourism-led growth hypothesis in Malaysia? Evidence from disaggregated tourism markets. Tourism Management, 37, 52-57.

Todaro, M.P. \& Smith, S.C. (2011). Development Economics. 11 $1^{\text {th }}$ ed. Harlow, England: Pearson Education Limited.

Tóth, A. A. (2016). The Impact of the Hotel Industry on the Competitiveness of Tourism Destinations in Hungary. Journal of Competitiveness, 8(4), 85-104.

Uddin, P.S.O. \& Uddin, O.O. (2013). Causes, Effects and Solutions to Youth Unemployment Problems in Nigeria. Journal of Emerging Trends in Economics and Management Sciences, 4(4), 397-402.

UNDP (United Nations Development Programme). (2016). Human development report. Madrid, Spain.

UNWTO (United Nations World Tourism Organization). (2014). Measuring employment in the tourism industries: Guide with best practice. Madrid, Spain.

UNWTO (United Nations World Tourism Organization). (2015). Over 1.1 billion tourist travelled abroad in 2014. Tourism Press Release No 15006, 27 January (2015). http://media.unwto.org/press-release. Retrieved 29 January 2018).

UNWTO (United Nations World Travel Organization). (2016). Tourism highlights. Madrid, Spain.

UNWTO (United Nations World Travel Organization). (2017a). Sustained growth in international tourism despite challenges. Press release no PR 17003. 17 January 2017. Madrid, Spain.

UNWTO (United Nations World Travel Organization). (2017b). World tourism barometer. Madrid, Spain.

Van Aardt, C., Van Aardt, I. \& Bezuidenhout, S. (2000). Entrepreneurship and new venture management. Cape Town: Oxford University Press.

Webster, C. \& Ivanov, S. (2014). Transforming Competitiveness into economic benefits: Does tourism simulate economic growth in more competitive destinations. Tourism Management, 40, 137-140.

WEF (World Economic Forum). (2017). Travel and Tourism Competitiveness Report 2017. Geneva, Switzerland.

World Bank. (2001). Poverty. Retrieved April 27, 2018 from http://data.worldbank.org/topic/poverty?locations=ZA. 
World Bank. (2017). GDP growth (annual \%). Retrieved April 27, 2018 http://data.worldbank.org/indicator/NY.GDP.MKTP.KD.ZG?locations=ZA.

WTTC (World Travel and Tourism Council). (2016). Travel and Tourism: Economic impact 2016. London, United Kingdom. 